\title{
Factors Associated with Growth Retardation in Children Suffering from Sickle Cell Anemia: First Report from Central Africa
}

\author{
Aimé Lukusa Kazadi, ${ }^{1}$ René Makuala Ngiyulu, ${ }^{1}$ Jean Lambert Gini-Ehungu, ${ }^{1}$ \\ Jean Marie Mbuyi-Muamba, ${ }^{2}$ and Michel Ntetani Aloni ${ }^{1}$ \\ ${ }^{1}$ Division of Paediatric Haemato-Oncology and Nephrology, Department of Paediatrics, University Hospital of Kinshasa, \\ Faculty of Medicine, University of Kinshasa, Kinshasa, Democratic Republic of the Congo \\ ${ }^{2}$ Department of Internal Medicine, Faculty of Medicine, University of Kinshasa, Kinshasa, Democratic Republic of the Congo \\ Correspondence should be addressed to Aimé Lukusa Kazadi; aimekaz@yahoo.fr
}

Received 13 August 2016; Accepted 7 November 2016; Published 30 January 2017

Academic Editor: Aurelio Maggio

Copyright @ 2017 Aimé Lukusa Kazadi et al. This is an open access article distributed under the Creative Commons Attribution License, which permits unrestricted use, distribution, and reproduction in any medium, provided the original work is properly cited.

Background. The aim of this study was to investigate and determine the risk factors associated with poor growth among SCA children. Methods. A cross-sectional study was conducted in Kinshasa, the capital's country. The nutritional status was assessed using the $\mathrm{Z}$ scores of the anthropometric indices. Results. We gathered data on the 256 patients, 138 females (53.9\%), who entered the study. The mean age at presentation was $8.4 \pm 4.9$ years of age. Underweight, stunting, and wasting were found, respectively, in $47.7 \%, 10.5 \%$, and $50.3 \%$ of SCA children. A history of hand-foot syndrome, more than 3 blood transfusions, being less than 12 months of age when receiving the first transfusion, more than two severe sickle crises per year, a medical history of severe infections, and the presence of hepatomegaly were associated with poor growth. When comparing sickle cell patients under 12 years of age $(n=159)$ to a group of 296 age-matched children with normal Hb-AA, a significantly higher proportion of subjects with stunting and underweight were found among SCA. Conclusion. Nutritional status encountered in Congolese sickle cell children has been described for the first time in this study. A high prevalence of poor growth in SCA children was found in our study.

\section{Introduction}

Sickle cell anaemia (SCA) is the commonest genetic diseases in sub-Saharan Africa [1]. In the Democratic Republic of Congo (DRC), the $\mathrm{HBB}^{*} S$ allele prevalence in neonates ranges from $0.96 \%$ to $1.4 \%$. According to 2010 estimation, the DRC contributed to the global burden of SCA with 39,800 [CI: 32,600-48,800] neonates each year [2].

SCA is an inflammatory disease characterized by chronic haemolysis, vasoocclusive crises, severe infection, and organ damage [1]. It is known that the sickle cell neonates have a normal weight at birth $[3,4]$. However, the disease with its attendant increased energy requirements has a negative effect on growth with a slow prepubertal growth and a delayed velocity compared with normal children [5]. Many factors as endocrine and/or metabolic dysfunction, haematological status, and nutritional status may play an important role in growth failure $[5,6]$.

Great progress has been made in the care of children with SCA in recent decades [7, 8]. Management of this haemoglobinopathy has been changing and is excellent as we have patients with advanced age in developed countries $[8,9]$. However, in developing countries such as the DRC, these cures are compromised by financial, human and laboratories resources deficiencies, inconsistent drug supplies, and delayed time of diagnosis [10, 11].

The determinants of low growth are not well understood and are probably due to phenotypic polymorphism due to haplotype, genetics factors, foetal haemoglobin level, specific nutrient deficiencies, and environmental factors [12-14]. 
Most studies are performed in sickle cell patients living in variable conditions that may affect growth and contribute to the difficulty to understand the mechanisms of growth in this population [15].

In the Democratic Republic of Congo (DRC), there is still very little information on nutritional status of children with SCA, because most provinces of this country lack paediatricians and vital hospital statistics scarcely contain sur information [16]. Additionally, $80 \%$ of the population lives in extreme poverty and more than $70 \%$ are estimated to suffer from malnutrition. Furthermore, the severity of the disease added to the poverty living conditions may influence the sickle cell children's growth curve [17]. Despite the high incidence and prevalence of SCA and the risk of failure to thrive in these patients, there was a paucity of studies from Central Africa, highlighting a large knowledge gap for lowresource settings.

It is necessary for health planning to have the main characteristics of children with SCA living in the DRC. This information will give the whole view of patients and may serve to rule out public health and in-hospital politics in our midst.

Thus, the aim of this study was to determine the prevalence and secondly to investigate the risk factors associated with failure to thrive among SCA children living in Kinshasa, the DRC. Our findings were compared to the results of previous studies reported in the literature.

\section{Methods}

This cross-sectional study was conducted in three paediatric health facilities in Kinshasa, namely, Centre de santé Saint Sacrement de Binza (West), the Sickle Cell Center of Yolo (Centre), and Centre de Santé Saint Marc (East). These health facilities provide most of the paediatric sickle cell followup in Kinshasa, DRC. These hospitals also provide most of the nonprivate paediatrics beds in Kinshasa for sickle cell patients.

Patients were consecutively selected in the outpatient clinic of the three health institutions. For the growth comparison, each sickle cell child under twelve years of age was matched with one or two control AA children for age, sex, and place of residence.

The following clinical and laboratory information were collected and analyzed: (i) demographic characteristics, (ii) anthropometric parameters, (iii) age at the first pain crisis and at the first blood transfusion, (iv) number of severe sickle cell crises per year, (v) blood transfusion, and (vi) haematologic parameters.

\section{Data Collection Procedure and Analysis}

Height and weight were measured using standardized techniques. Weighing scale was calibrated to zero before taking every measurement. The children were weighed with minimum clothing and without shoes.

Measurement of height was done in a lying position with wooden board for children under 2 years of age and measurement of height for children over 2 years of age was in a standing position in centimeters to the nearest $1 \mathrm{~cm}$.

The nutritional status of the study population was assessed using the $\mathrm{Z}$ scores of the anthropometric indices: weight-for-height $\mathrm{Z}$ score (WHZ), height-for-age $\mathrm{Z}$ score (HAZ), and weight-for-age $\mathrm{Z}$ score (WAZ). These indicators were calculated according to the references of the National Centre for Health Statistics/WHO/CDC [18]. Abnormal status is defined as having an indicator $\mathrm{Z}$ score less than -2.0. WHZ determined the severity of wasting, HAZ the severity of stunting, and WAZ underweight.

At the end, the nutritional status of SCA patients was compared to healthy peers age-matched haemoglobin-AA group. Because sex steroid hormones effects on the growth pattern start on average at 12 [19], we only compare children under 12 years of age for this purpose, in both groups.

Blood samples were collected from all subjects. Sickle cell screening was performed using isoelectric focusing (IEF) technique with the Multiphor II apparatus (GE Healthcare, Little Chalfont, England). The separation of different haemoglobin (F, A, S, and other types of haemoglobin) was obtained after application on thin layer home-made agarose gel containing ampholytes pH 6-8 (ref. 2117-003; Pharmalyte pH 6.7-7.7; GE Healthcare).

\section{Data Management}

The information that was obtained was analyzed using Epi info version 6 (CDC). After data cleaning (control for quality and coherence), they were exported on SPSS 22.0 for further analysis. All data from discrete variables are represented as means \pm standard deviation (SD). Frequency of various clinical and laboratory findings are expressed as percentages. The confidence interval at $95 \%$ was calculated. Pearson chisquare or Fisher's exact test was used to assess differences in categorical data between groups. The analysis of Student's $t$-test or Mann-Whitney test was used for comparisons of means. The relationship between growth in SCA children and study parameters was assessed using logistic regression models. Odds ratios were provided with their 95\% confidence interval (95\% CI) and were estimated for the factors that have a significant effect. A $p$ value $<0.05$ was considered significant.

\section{Results}

5.1. Study Population and Baseline Characteristics. We gathered data on the 256 patients, 138 females (53.9\%) and 118 males $(46.1 \%)$, who entered the study. The mean age at presentation was $8.4 \pm 4.9$ years of age. Table 1 presents baseline characteristics of all patients.

5.2. Risk of Short Stature. Growth in height fell below the 5th percentile in $7.8 \%(n=20)$ of sickle cell children. A history of hand-foot syndrome and the number of transfusions of more than 3 per patient were associated with an increased risk of short stature with OR, respectively, 4.3 and 4.8. However, the presence of hepatomegaly was also associated (OR 4.2) but with a nonsignificant CI 95\%. All results are shown in Table 2. 
TABLE 1: Characteristics of the study population.

\begin{tabular}{|c|c|}
\hline Parameters & $\begin{array}{l}\text { Patients } \\
(n=256)\end{array}$ \\
\hline \multicolumn{2}{|l|}{ Age, years } \\
\hline Mean (SD) & $8.4 \pm 4.9$ \\
\hline \multicolumn{2}{|l|}{ Age distribution, years } \\
\hline$<4$ years, $n(\%)$ & $(31.6)$ \\
\hline $5-9$ years, $n(\%)$ & $(32.5)$ \\
\hline $10-14$ years, $n(\%)$ & $(25)$ \\
\hline$\geq 15$ years, $n(\%)$ & $(10.9)$ \\
\hline \multicolumn{2}{|l|}{ Gender } \\
\hline Male, $n(\%)$ & $118(46.1)$ \\
\hline Female, $n(\%)$ & $138(53.9)$ \\
\hline \multicolumn{2}{|l|}{ Anthropometrics parameters } \\
\hline Mean weight (kg) (range) & $20.6 \pm 9.8(7-62)$ \\
\hline Mean height (cm) (range) & $115 \pm 24(63-172)$ \\
\hline Mean BMI, (range) ${ }^{*}$ & $17.0 \pm 1.8(10.9-22.9)$ \\
\hline \multicolumn{2}{|l|}{ Clinical findings } \\
\hline Hepatomegaly, $n$ (\%) & $136(53.1)$ \\
\hline Splenomegaly, $n(\%)$ & $109(41.7)$ \\
\hline \multicolumn{2}{|l|}{ Sickle cell crises } \\
\hline Haemolysis, $n(\%)$ & $136(53.1)$ \\
\hline Severe pain crisis, $n(\%)$ & $170(66.4)$ \\
\hline Hand-foot syndrome, $n(\%)$ & $85(33.2)$ \\
\hline Severe infection, $n(\%)$ & $45(17.6)$ \\
\hline splenic sequestration, $n(\%)$ & $19(7.4)$ \\
\hline $\begin{array}{l}\text { Mean age at the first pain crisis } \\
\text { (range), months }\end{array}$ & $18.2 \pm 15.2(2-108)$ \\
\hline $\begin{array}{l}\text { Mean age at the first transfusion } \\
\text { (range), months }\end{array}$ & $29.2 \pm 27.6(2-132)$ \\
\hline $\begin{array}{l}\text { Number of severe pain } \\
\text { crises/year, } n \text { (range) }\end{array}$ & $3.5 \pm 2.9(1-20)$ \\
\hline $\begin{array}{l}\text { Number of blood transfusions, } n \\
\text { (range) }\end{array}$ & $4.1 \pm 3.2(0-30)$ \\
\hline \multicolumn{2}{|l|}{ Laboratory features } \\
\hline Mean $\mathrm{Hb}(\mathrm{g} / \mathrm{dl})(\text { range })^{*}$ & $7.4 \pm 1.5(4.3-11)$ \\
\hline Mean Ht $(\%)(\text { range })^{*}$ & $23.2 \pm 4.5(12.2-35)$ \\
\hline Mean WBCs $\left(10^{3} / \mathrm{mm}^{3}\right)(\text { range })^{*}$ & $14.5 \pm 5.4(4.6-34.2)$ \\
\hline Mean platelets $\left(10^{3} / \mathrm{mm}^{3}\right)$ (range) & $315.5 \pm 118.5(114-582)$ \\
\hline
\end{tabular}

*BMI, body mass index; Hb, hemoglobin; Ht, hematocrit; WBCs, white blood cells.

5.3. Underweight, WAZ. In this series, underweight was found in $47.7 \%(n=122)$ of SCA children. The presence of hepatomegaly was weakly associated with an increased risk of wasting.

5.4. Stunting TAZ. In this series, stunting was found in $10.5 \%$ $(n=27)$ of SCA children. Number of severe sickle cell crises of more than two per year, age at the first blood transfusion less than 12 months, and number of blood transfusions of more than three per patient were associated with an increased risk of stunting (Table 2).
TABLE 2: Factors associated with a risk of stunting in the study population.

\begin{tabular}{|c|c|c|c|}
\hline Variables & OR & CI 95\% & $p$ \\
\hline \multicolumn{4}{|l|}{ Underweight, WAZ } \\
\hline Hepatomegaly & & & $<0.05$ \\
\hline Absence & 1 & & \\
\hline Presence & 1.4 & $1-1.8$ & \\
\hline \multicolumn{4}{|l|}{ TAZ, risk of wasting } \\
\hline $\begin{array}{l}\text { Number of sickle cell } \\
\text { crises/year }\end{array}$ & & & $<0.01$ \\
\hline$\leq 2$ & 1 & - & \\
\hline$>2$ & 3.8 & $1.5-9.5$ & \\
\hline Age at the first transfusion & & & $<0.01$ \\
\hline$>12$ months & 1 & - & \\
\hline$\leq 12$ months & 3.3 & $1.1-9.3$ & \\
\hline Number of blood transfusions & & & $<0.05$ \\
\hline$\leq 3$ & 1 & - & \\
\hline$>3$ & 2.5 & $1.1-6$ & \\
\hline \multicolumn{4}{|l|}{ Risk of short stature } \\
\hline Hand-foot syndrome & & & $<0.01$ \\
\hline Absence & 1 & - & \\
\hline Present & 4.3 & $1.3-13.7$ & \\
\hline Number of blood transfusions & & & $<0.05$ \\
\hline$\leq 3$ & 1 & - & \\
\hline$>3$ & 4.8 & $1.1-21.5$ & \\
\hline Hepatomegaly & & & $<0.05$ \\
\hline Absence & 1 & - & \\
\hline Presence & 4.2 & $0.94-18.9$ & \\
\hline \multicolumn{4}{|l|}{ Wasting WHZ } \\
\hline Hand-foot syndrome & & & $<0.01$ \\
\hline Absence & 1 & - & \\
\hline Present & 1.7 & $1.2-2.5$ & \\
\hline Severe infections & & & $<0.05$ \\
\hline Absence & 1 & - & \\
\hline Presence & 1.8 & $1.0-3.1$ & \\
\hline Number of blood transfusions & & & $<0.05$ \\
\hline$\leq 3$ & 1 & - & \\
\hline$>3$ & 1.3 & $1.0-1.7$ & \\
\hline
\end{tabular}

5.5. Wasting WHZ. According the WHZ, wasting was found in $50.3 \%(n=129)$ of SCA children. A history of hand-foot syndrome is the main factor associated with an increased risk of wasting. Other factors such as history of severe infections and the number of transfusions of more than 3 per patient were weakly associated.

5.6. Comparison with Normal Children (Hb-AA). Among children under 12, a significantly higher proportion $(34.9 \%)$ of subjects with stunting were children with $\mathrm{Hb}$-SS, compared to $9.8 \%$ in children with $\mathrm{Hb}-\mathrm{AA}$. Additionally, more than a third $(39.8 \%)$ of subjects with underweight were children 
TABLE 3: Nutritional status according to $\mathrm{Hb}$ status in children under 12 years of age in the study population.

\begin{tabular}{lccc}
\hline Variables & Hb-SS, $n=159$ & $\mathrm{Hb}-\mathrm{AA}, n=296$ & $p$ \\
\hline $\begin{array}{l}\text { Stunting TAZ, } n(\%) \\
\text { Wasting WHZ, } n\end{array}$ & $55(34.6 \%)$ & $29(9.8 \%)$ & $<0.001$ \\
$\begin{array}{l}(\%) \\
\text { Underweight WAZ, } \\
n(\%)\end{array}$ & $63(39.6 \%)$ & $36(12.5 \%)$ & $\mathrm{NS}$ \\
\hline
\end{tabular}

with $\mathrm{Hb}-\mathrm{SS}$, compared to $12.2 \%$ in children with $\mathrm{Hb}-\mathrm{AA}$ (Table 3).

In Hb-SS group, the prevalence of wasting (WHZ) tended to be higher than $\mathrm{Hb}-\mathrm{AA}$ groups. However, there was no statistically significant difference between the two groups (Table 3).

\section{Discussion}

The aim of study is oriented to identify the factors associated with failure to thrive in a paediatric population. In Central Africa, a predominant region of Bantu haplotype, there is anecdotal information on growth in paediatric population suffering from SCA [20]. Our study is the first to investigate and determine the risk factors associated with failure to thrive among SCA children living in Kinshasa, the capital's country of the DRC.

Before going through discussing our results, it appears important to explain difficulties when using growth chart from different populations. Ideally, local charts would give better insight of the real situation and local realities. Unfortunately, to the better of our knowledge, available references for growth studies in our midst are the ones we used here from the National Centre for Health Statistics/WHO/CDC [18]. The advantage would be to have an international standard growth chart which allows comparison of children in different settings around the world.

Growth in height fell below the 5 th percentile in $7.8 \%$ of sickle cell children. Similar observations on short stature were reported in other worldwide studies where the proportion varies from $5 \%$ to $54 \%[5,21-24]$. These wide variations are probably due to sample size, selection of reference growth data, and environmental and genetics factors which limited comparability between these studies.

A history of hand-foot syndrome, the number of transfusions of more than 3 per patient, and the presence of hepatomegaly were associated with an increased risk of short stature. These trends are in accordance with the results found in the literature [25].

In this series, underweight was found in $47.7 \%$ of SCA children. Similar observations were reported in other worldwide studies [24, 26-28]. The presence of hepatomegaly was weakly associated with an increased risk of wasting. This observation is probably due to the predominance of SCA without $\alpha \alpha+$ thalassemia in Central Africa et the severity of this phenotype $[29,30]$. In contrast to our findings, AlSaqladi et al. found an association of low height-for-age $\mathrm{Z}$ score with increased age [22]. These differences between our study and the Yemen study presumably arise from differences in environmental and genetic factors that influence growth of sickle cell children

In this series, stunting was found in $10.5 \%(n=27)$ of SCA children. These results are in consonance with previous studies where the prevalence varies from $16.4 \%$ to $43 \%$ [20, $24,27,31]$. Number of severe sickle cell crises of more than two per year, age at the first blood transfusion less than 12 months, and number of blood transfusions of more than three per patient were associated with an increased risk of stunting. This may find explanation as these factors provide a trend of the severity of the disease. The severity of the clinical manifestations of the disease increases the energy expenditure and decreases the calorie intake [32]. The results found in this cohort confirm and extend the findings of several studies $[20,25,33]$. In contrast, Al-Saqladi et al. found an association of low height-for-age $\mathrm{Z}$ score with male gender in their series [22]. These differences between our study and the Yemen study presumably arise from differences in environmental and genetic factors that influence growth of sickle cell children.

According the WHZ, wasting was found in half of our of SCA children (50.3\%). This prevalence is higher than the results reported by Henderson et al. in USA where $11 \%$ of sickle cell children were affected [31]. These differences may be due to selection of reference growth data and environmental and genetics factors. Only a history of hand-foot syndrome is strongly associated with an increased risk of wasting, while severe infections and the number of transfusions of more than 3 per patient were weakly associated. This is in accordance with those reported by other authors [24, 25]. In contrast, Al-Saqladi et al. in Yemen found an association of low weight-for-height $\mathrm{Z}$ score with increased age [22]. These differences between our study and the US study presumably arise from differences in environmental and genetic factors that influence growth of sickle cell children.

In this series, age, gender, increased volume of tonsil, age at the first transfusion, splenic sequestration, WBCs, and platelets levels were not associated with poor growth as described by other authors [31]. In contrast, these parameters were found to be associated with poor growth in previous worldwide studies $[3,20]$. These differences between these studies presumably arise from differences in environmental and genetic factors that influence growth of sickle cell children.

From these findings, only little explanation may be advanced and speculated. Underweight and wasting are probably due to phenotypic polymorphism due to haplotype, genetics factors, fetal haemoglobin level, specific nutrient deficiencies, and environmental factors [12-14]. Indeed, the Bantu haplotype is predominant and the Congolese SCA patients displayed low levels of fetal haemoglobin $(\mathrm{HbF})$ and F-cells that contribute to the severity of SCA [34]. To the best of our knowledge, it appears that factors associated with growth in SCA children are those that characterize more severe disease.

A significantly higher proportion of subjects with stunting were children with $\mathrm{Hb}$-SS, compared to $9.8 \%$ in children with $\mathrm{Hb}-\mathrm{AA}$. The HAZ (stunting) scores were significantly 
more common among SCD children than controls, in previous worldwide studies $[20,35,36]$. In contrast, Barden et al. in Nigeria found no significant difference between normal and sickle cell children [36]. These differences between our study and the US study presumably arise from differences in environmental and genetic factors that influence growth of sickle cell children. Limitation from our study may arise in the fact that we did not assess nutritional intake of each patient as this was not the aim of the study. Mandese et al. showed that inadequate nutritional intake, weight, and Body Mass Index have significant impact on SCA severity indices such as number of hospital admissions per year, days of hospital admission per year, and mean haemoglobin $\mathrm{F}$ [32].

A significantly higher proportion (39.6\%) of subjects being underweight were children with $\mathrm{Hb}-\mathrm{SS}$, compared to $(12.2 \%)$ in children with Hb-AA. This observation is comparable with previous studies in African countries [35, 36]. In Hb-SS group, the prevalence of wasting (WH-Z score) tended to be higher than Hb-AA groups. However, there was no statistically significant difference between the two groups. This observation is also reported by previous studies in African and worldwide countries [35-38]. In USA, Malinauskas et al. found that WHZ did not differ from national reference data [25]. However, the sample size of the US study was limited to children under 6 years of age. This pattern is understandable because early event has by itself less impact on a chronic disease, and growth processes into phases which are influenced by different hormones [19].

The present study had some limitations due to its hospital-based cross-sectional design and a retrospective chart review. One additional limitation was biological measurements to perform during the study. Also, as Kinshasa accounts only for $15 \%$ of the DRC population, this study may not necessarily reflect the overview of the whole country. But this should be the general trend since our patients came from all different socioeconomic areas. Despite these limitations, these data provide insights into the relationship between poor growth and SCA in our midst.

\section{Conclusion}

Nutritional status encountered in Congolese sickle cell children has been described for the first time in this study. A high prevalence of poor growth in SCA children was found and was associated with more severe disease estimated by several clinical characteristics in our study. Stunting is more common compared to underweight in SCA children. These results reflect the chronicity of SCA. Additionally, Congolese SCA children are more underweight, wasted, and stunted than the $\mathrm{Hb}-\mathrm{AA}$ children. The high prevalence of sickle cell anaemia in Sub-Saharan Africa underlines the need for screening of all SCA children to identify patients with the risk of developing poor growth and provide early management. Furthermore, our results strongly suggest that more research in our midst would provide valuable insights into the pathogenesis of poor growth.

\section{Competing Interests}

The authors have no conflict of interests to disclose.

\section{Authors' Contributions}

Aimé Lukusa Kazadi, Jean Marie Mbuyi-Muamba, Michel Ntetani Aloni, and Jean Lambert Gini-Ehungu conceived, designed, deployed, and directed the study at the Department of Paediatrics at Kinshasa University Hospital and wrote the manuscript. Aimé Lukusa Kazadi carried out recruitment and follow-up, sample collection, storage, and transport. Aimé Lukusa Kazadi and Michel Ntetani Aloni brought some precious corrections. Aimé Lukusa Kazadi, Jean Marie Mbuyi-Muamba, René Makuala Ngiyulu, and Michel Ntetani Aloni analyzed data. Michel Ntetani Aloni and Aimé Lukusa Kazadi edited the English and made corrections. All authors read and approved the final manuscript.

\section{Acknowledgments}

The authors acknowledge all the physicians and nurses of the three health institutions of Kinshasa, DRC, for their assistance in collecting the data.

\section{References}

[1] D. C. Rees, T. N. Williams, and M. T. Gladwin, "Sickle-cell disease," The Lancet, vol. 376, no. 9757, pp. 2018-2031, 2010.

[2] F. B. Piel, S. I. Hay, S. Gupta, D. J. Weatherall, and T. N. Williams, "Global burden of sickle cell anaemia in children under five, 2010-2050: modelling based on demographics, excess mortality, and interventions," PLoS Medicine, vol. 10, no. 7, Article ID e1001484, 2013.

[3] C. K. Phebus, M. F. Gloninger, and B. J. Maciak, "Growth patterns by age and sex in children with sickle cell disease," The Journal of Pediatrics, vol. 105, no. 1, pp. 28-33, 1984.

[4] O. S. Platt, W. Rosenstock, and M. A. Espeland, "Influence of sickle hemoglobinopathies on growth and development," The New England Journal of Medicine, vol. 311, no. 1, pp. 7-12, 1984.

[5] B. S. Zemel, D. A. Kawchak, K. Ohene-Frempong, J. I. Schall, and V. A. Stallings, "Effects of delayed pubertal development, nutritional status, and disease severity on longitudinal patterns of growth failure in children with sickle cell disease," Pediatric Research, vol. 61, no. 5, part 1, pp. 607-613, 2007.

[6] A. Singhal, J. Morris, P. Thomas, G. Dover, D. Higgs, and G. Serjeant, "Factors affecting prepubertal growth in homozygous sickle cell disease," Archives of Disease in Childhood, vol. 74, no. 6, pp. 502-506, 1996.

[7] L. Iughetti, E. Bigi, and D. Venturelli, "Novel insights in the management of sickle cell disease in childhood," World Journal of Clinical Pediatrics, vol. 5, no. 1, pp. 25-34, 2016.

[8] S. Chaturvedi and M. R. Debaun, "Evolution of sickle cell disease from a life-threatening disease of children to a chronic disease of adults: the last 40 years," American Journal of Hematology, vol. 91, no. 1, pp. 5-14, 2016.

[9] N. Matthie and C. Jenerette, "Sickle cell disease in adults: developing an appropriate care plan," Clinical Journal of Oncology Nursing, vol. 19, no. 5, pp. 562-568, 2015.

[10] T. N. Williams, "Sickle cell disease in Sub-Saharan Africa," Hematology/Oncology Clinics of North America, vol. 30, no. 2, pp. 343-358, 2016.

[11] M. N. Aloni and L. Nkee, "Challenge of managing sickle cell disease in a pediatric population living in kinshasa, democratic 
republic of congo: a sickle cell center experience," Hemoglobin, vol. 38, no. 3, pp. 196-200, 2014.

[12] A. Habara and M. H. Steinberg, "Minireview: genetic basis of heterogeneity and severity in sickle cell disease," Experimental Biology and Medicine, vol. 241, no. 7, pp. 689-696, 2016.

[13] P. Bhatnagar, S. Purvis, E. Barron-Casella et al., "Genome-wide association study identifies genetic variants influencing F-cell levels in sickle-cell patients," Journal of Human Genetics, vol. 56, no. 4, pp. 316-323, 2011.

[14] W. R. Smith, P. Coyne, V. S. Smith, and B. Mercier, “Temperature changes, temperature extremes, and their relationship to emergency department visits and hospitalizations for sickle cell crisis," Pain Management Nursing, vol. 4, no. 3, pp. 106-111, 2003.

[15] A.-W. M. Al-Saqladi, R. Cipolotti, K. Fijnvandraat, and B. J. Brabin, "Growth and nutritional status of children with homozygous sickle cell disease," Annals of Tropical Paediatrics, vol. 28, no. 3, pp. 165-189, 2008.

[16] S. Wembonyama, S. Mpaka, and L. Tshilolo, "Medicine and health in the democratic republic of congo: from independence to the third republic," Médecine Tropicale (Mars), vol. 67, no. 5, pp. 447-457, 2007.

[17] S. Tewari, V. Brousse, F. B. Piel, S. Menzel, and D. C. Rees, "Environmental determinants of severity in sickle cell disease," Haematologica, vol. 100, no. 9, pp. 1108-1116, 2015.

[18] WHO Multicentre Growth Reference Study Group, WHO Child Growth Standards: Length/Height-for-Age, Weight-for-Age, Weight-for-Length, Weight-for-Height and Body Mass Index-forAge: Methods and Development, World Health Organization, Geneva, Switzerland, 2006.

[19] J. Karlberg, "A biologically-oriented mathematical model (ICP) for human growth," Acta Paediatrica Scandinavica, Supplement, vol. 78, no. 350, pp. 70-94, 1989.

[20] J. R. Mabiala-Babela, A. Massamba, J. B. Tsiba, J. G. A. Moulongo, S. Nzingoula, and P. Senga, "Body composition in Negro African children suffering from sickle cell disease. A mixed cross-sectional longitudinal study in Brazzaville, Congo," Bulletin de la Societe de Pathologie Exotique, vol. 98, no. 5, pp. 394399, 2005.

[21] Z. D. Nogueira, N. Boa-Sorte, M. E. D. Q. Leite, M. M. Kiya, T. Amorim, and S. F. D. Fonseca, "Breastfeeding and the anthropometric profile of children with sickle cell anemia receiving follow-up in a newborn screening reference service," Revista Paulista de Pediatria, vol. 33, no. 2, pp. 154-159, 2015.

[22] A.-W. M. Al-Saqladi, H. A. Bin-Gadeen, and B. J. Brabin, "Growth in children and adolescents with sickle cell disease in Yemen," Annals of Tropical Paediatrics, vol. 30, no. 4, pp. 287298, 2010.

[23] H. I. Hyacinth, O. A. Adekeye, and C. S. Yilgwan, "Malnutrition in sickle cell anemia: implications for infection, growth, and maturation," Journal of Social, Behavioral and Health Sciences, vol. 1, no. 1, pp. 1-7, 2013.

[24] M. J. Mitchell, G. J. O. Carpenter, L. E. Crosby, C. T. Bishop, J. Hines, and J. Noll, "Growth status in children and adolescents with sickle cell disease," Pediatric hematology and oncology, vol. 26, no. 4, pp. 202-215, 2009.

[25] B. M. Malinauskas, S. S. Gropper, D. A. Kawchak, B. S. Zemel, K. Ohene-Frempong, and V. A. Stallings, "Impact of acute illness on nutritional status of infants and young children with sickle cell disease," Journal of the American Dietetic Association, vol. 100, no. 3, pp. 330-334, 2000.
[26] O. Modebe and S. A. Ifenu, "Growth retardation in homozygous sickle cell disease: role of calorie intake and possible genderrelated differences," American Journal of Hematology, vol. 44, no. 3, pp. 149-154, 1993.

[27] F. I. D. Konotey-Ahulu, The Sickle Cell Disease Patient, TettehA’Domeno, Watford, UK, 1996.

[28] A. Chawla, P. G. Sprinz, J. Welch et al., "Weight status of children with sickle cell disease," Pediatrics, vol. 131, no. 4, pp. el168el173, 2013.

[29] I. Lubega, C. M. Ndugwa, E. A. Mworozi, and J. K. Tumwine, "Alpha thalassemia among sickle cell anaemia patients in Kampala, Uganda," African Health Sciences, vol. 15, no. 2, pp. 682-689, 2015.

[30] R. Mouélé, O. Pambou, J. Feingold, and F. Galactéros, “ $\alpha$ thalassemia in Bantu population from Congo-Brazzaville: its interaction with sickle cell anemia," Human Heredity, vol. 50, no. 2, pp. 118-125, 2000.

[31] R. A. Henderson, J. M. Saavedra, and G. J. Dover, "Prevalence of impaired growth in children with homozygous sickle cell anemia," The American Journal of the Medical Sciences, vol. 307, no. 6, pp. 405-407, 1994.

[32] V. Mandese, F. Marotti, L. Bedetti, E. Bigi, G. Palazzi, and L. Iughetti, "Effects of nutritional intake on disease severity in children with sickle cell disease," Nutrition Journal, vol. 15, no. 1, p. 46, 2016.

[33] M. Reid, "Nutrition and sickle cell disease," Comptes Rendus Biologies, vol. 336, no. 3, pp. 159-163, 2013.

[34] L. Tshilolo, V. Summa, C. Gregorj et al., "Foetal haemoglobin, erythrocytes containing foetal haemoglobin, and hematological features in Congolese patients with sickle cell anaemia," Anemia, vol. 2012, Article ID 105349, 7 pages, 2012.

[35] C. Osei-Yeboah, O. Rodrigues, and C. Enweronu-Laryea, "Nutritional status of children with sickle cell disease at Korle $\mathrm{Bu}$ Teaching Hospital, Accra, Ghana," West African Journal of Medicine, vol. 30, no. 4, pp. 262-267, 2011.

[36] E. M. Barden, D. A. Kawchak, K. Ohene-Frempong, V. A. Stallings, and B. S. Zemel, "Body composition in children with sickle cell disease," American Journal of Clinical Nutrition, vol. 76, no. 1, pp. 218-225, 2002.

[37] S. O. Akodu, I. N. Diaku-Akinwumi, O. A. Kehinde, and O. F. Njokanma, "Evaluation of arm span and sitting height as proxy for height in children with sickle cell anemia in Lagos, Nigeria," Journal of the American College of Nutrition, vol. 33, no. 6, pp. 437-441, 2014.

[38] B. A. Animasahun, E. O. Temiye, O. O. Ogunkunle, A. N. Izuora, and O. F. Njokanma, "The influence of socioeconomic status on the hemoglobin level and anthropometry of sickle cell anemia patients in steady state at the Lago; University Teaching Hospital," Nigerian Journal of Clinical Practice, vol. 14, no. 4, pp. 422-427, 2011. 


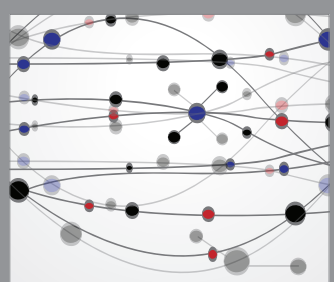

The Scientific World Journal
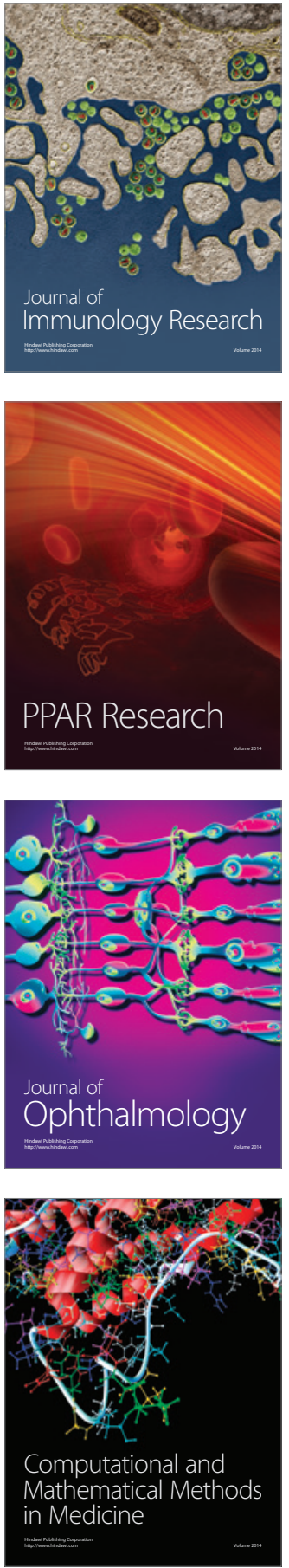

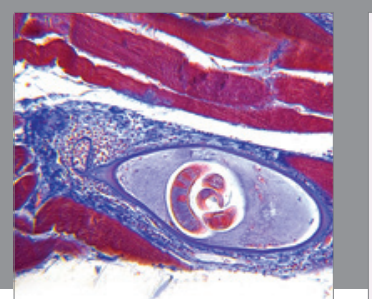

Gastroenterology Research and Practice
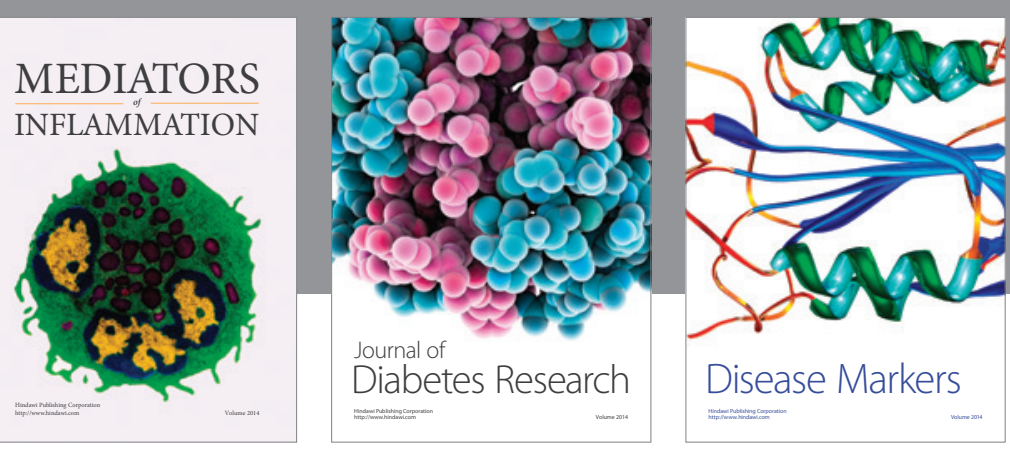

Disease Markers

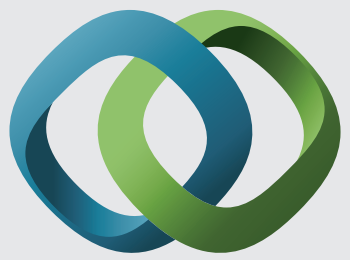

\section{Hindawi}

Submit your manuscripts at

https://www.hindawi.com
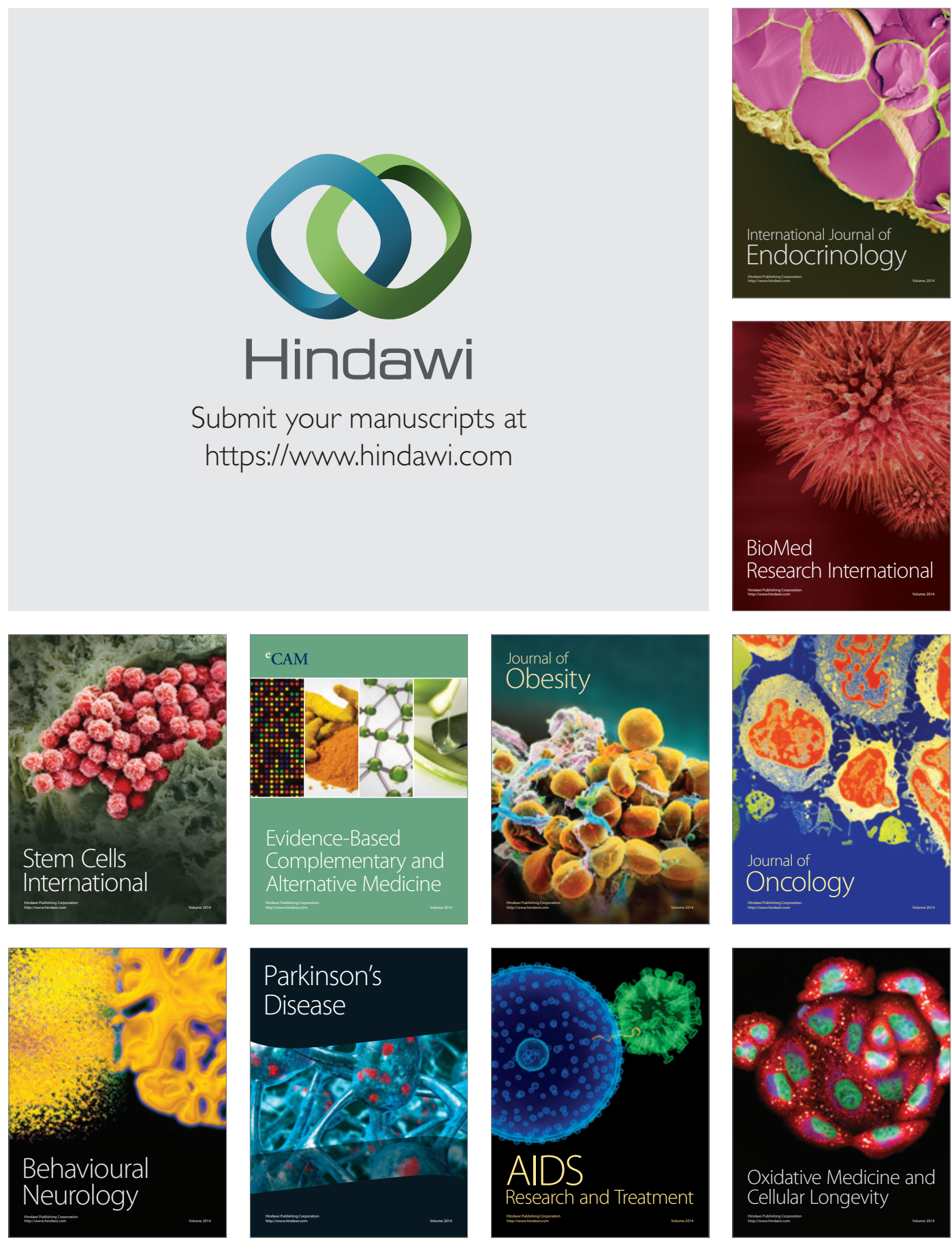